\title{
Cyclone Komen's aftermath: Local knowledge shows how poverty and inequalities fuel climate risk in western Myanmar
}

\author{
Laura Kmoch $^{1,2} \cdot$ Matilda Palm ${ }^{3}$ Ulf Martin Persson ${ }^{1} \cdot$ Martin Rudbeck Jepsen $^{4}$
}

Received: 19 March 2021 / Accepted: 2 October 2021 / Published online: 27 October 2021

(c) The Author(s) 2021, corrected publication 2022

\begin{abstract}
Cyclones and other extreme events exert increasing pressure on South-East Asia's societies and put smallholder farmers at risk. Here, we draw on participatory causal-diagramming workshops, interviews and survey data, to provide contextually grounded knowledge about rural communities' exposure and vulnerability to climate-related hazards in western Myanmar. By tracing how the 2015 cyclone Komen led to a prolonged humanitarian disaster, we show that climate-related risks in this area arise from the complex interplay of households' pre-existing vulnerabilities, persistent farming challenges, extensive disasters and cascading effects, which disparately affect lowland and upland communities. The different household strata's dissimilar vulnerabilities vis-à-vis Komen's impacts were rooted in the distinct exposure of their production systems to landslides and floods. Pre-existing land-access barriers, land-degradation processes, climatic stressors, agricultural pests and diseases, and chronic lack of assets and food insecurity further mediated households' vulnerability. Relief interventions did not stop the disaster's escalation, although this could have been achieved with early technical and material assistance to address the cyclone's impacts on farmers' land. Targeted aid for households facing imminent food insecurity or debt crisis could have lessened engagement in precarious coping strategies and distress migration. A diversification of households' livelihood and land-use practices and increased redundancies of critical assets and infrastructure could help to mitigate future cyclone-triggered disasters. By demonstrating the strengths of local knowledge approaches in untangling the complex interplay of extreme events with households' everyday vulnerabilities and agricultural land-use practices, we make a case for more contextually grounded disaster risk and climate adaptation research.
\end{abstract}

Keywords Climate vulnerability $\cdot$ Cascading disasters $\cdot$ Flooding $\cdot$ Poverty traps $\cdot$ Farming system challenges $\cdot$ Participatory causal diagramming

\section{Introduction}

'The water was very high', said a 68-year-old women near Kalay, 'a flood like this never happened before'. 'We could not leave [our village] for one week', explained a younger

Communicated by Chinwe Ifejika Speranza

Laura Kmoch

kmoch@chalmers.se

Matilda Palm

matilda.palm@viskogen.se

Ulf Martin Persson

martin.persson@chalmers.se

Martin Rudbeck Jepsen

mrj@ign.ku.dk

1 Department of Space, Earth and Environment, Chalmers

University of Technology, Gothenburg, Sweden man, 'after one week we ran out of food, we ran out of everything'. In late July and August 2015, a monsoon depression crossed the northern Chin Hills and adjacent Kalay valley in Myanmar, after it built up to cyclone strength over the Bay of Bengal (United Nations Office for the Coordination of Humanitarian Affairs 2015). No one knew yet just how severely cyclone Komen would affect livelihoods and

2 Present Address: Section for Social-Ecological Interactions in Agricultural Systems, Faculty of Organic Agricultural Sciences, University of Kassel, Steinstraße 19, 37213 Witzenhausen, Germany

3 Vi-Skogen, Stockholm, Sweden

4 Department of Geosciences and Natural Resource Management, University of Copenhagen, Copenhagen, Denmark 
farming systems in the area. That this extreme event exacerbated an already tense situation was clear, however: 'Heavy monsoon rains during the month of July, [... had] caused flooding, flash floods and landslides in several parts of Myanmar, including the Sagaing Region', to which cyclone Komen added, by triggering additional floods, landslides, intense rain and wind (United Nations Office for the Coordination of Humanitarian Affairs 2015, para. 1). Official figures eventually showed that the cyclone affected at least 9 million people, temporarily displaced 1.6 million, caused 149 deaths, and devastated 15,000 homes and almost 340 000 hectares of cropland (International Federation of Red Cross and Red Crescent Societies 2017). Myanmar's president declared natural disaster zones, including Chin State, Sagaing Region, Magway Region and Rakhine State, and major relief and recovery operations commenced (International Federation of Red Cross and Red Crescent Societies 2017).

Komen's traverse, and the subsequent disaster, are concrete manifestations of a pattern of increasingly frequent and intense heavy rainfall events that cause landslides, flooding and widespread human calamity, and put contemporary South-East Asian societies under pressure. Models predict that tropical cyclones will gain intensity as the planet warms (Gualdi et al. 2008; Knutson et al. 2010). It is also 'more likely than not' that the most intense tropical cyclones will become more frequent, whereas such events' overall frequency is projected to remain stable or decline (Knutson et al. 2010, p. 162). Cyclones in the lower Mekong countries already frequently cause floods, which have more severe negative impacts on human displacement and health than the region's average floods (Chen 2020). Moreover, cyclones in the area are projected to intensify, exacerbating associated risks to human security at regional scale (Chen 2020). River flood protection in Myanmar is currently virtually non-existent (Chen 2020), and hence, severe and recurrent floods are already an excruciating reality for Myanmar's numerous rural poor, who depend on land-based livelihood activities to meet basic needs (FloodList 2020; Hallegatte et al. 2020).

Research on the climate-poverty-livelihood nexus shows that poverty and climate-related disasters are co-constitutive (Hallegatte et al. 2020), which is also accepted wisdom in the disaster risk reduction and management community (United Nations Office for Disaster Risk Reduction 2019). The mechanism behind this relationship is that disaster risk, in addition to hazards, is a function of exposure and vulnerability (United Nations Office for Disaster Risk Reduction 2019). Both exposure and vulnerability to hazards are biassed, however, with poor people 'often, but not always [...] more likely to be affected by hazards', as they tend to live in more dangerous areas and are more vulnerable (Hallegatte et al. 2020, p. 223). Their asset portfolios are often less diversified and their assets of lower 'quality' than those of the non-poor (Hallegatte et al. 2020, p. 232). Poor people also 'tend to lose a larger fraction of their wealth' when a disaster occurs, increasing risks to being 'locked in poverty traps', and they 'have a lower ability to cope with and recover from disaster impacts' not only because they have less assets but also because 'they receive less support' (Hallegatte et al. 2020, p. 223, $233,240)$. Despite these relationships being relatively well understood, practical insights on how to break the vicious cycle of climate-related disaster risk and poverty are lacking in many regions. Local-scale climate risk assessments in many low- and middle-income countries remain scant, and rural peoples' exposure and vulnerability shifts in time with regional social-ecological system change, e.g. as societies adopt new agricultural practices, alter catchments' hydrology, or engage in new livelihood activities. Further research, unravelling the context-specific and dynamic nature of communities' exposure and vulnerability to climate risks is therefore needed, especially, where we know that hazards are set to increase. Here, we provide such an analysis for Myanmar's Chin Hills.

Myanmar's Climate Change Strategy recognises a need for decisive action to support the country's vulnerable rural poor in future-proofing their farming systems and livelihoods vis-à-vis regionally experienced climate stressors and global climate change (The Republic of the Union of Myanmar 2019). To succeed, such work needs grounding in knowledge about which climate hazards rural communities face, and how and why people are exposed and vulnerable to these hazards. Research on the latter, focused on ethnic upland regions (including Chin State, where this study is set), remains scant (Chitale et al. 2019), as most previous studies on climate risk focus on Myanmar's central dry zone and delta regions (e.g. Herridge et al. 2019; Schneider and Asch 2020; Tun Oo et al. 2018, 2017). Notable exceptions include a recent climate vulnerability assessment for Chin State's township Hakha, and Desportes' (2019) analysis of relief efforts for marginalised communities in Komen's wake.

Our case study, assessing Komen's impacts on farming systems and rural livelihoods in three townships (Tonzang, Tedim and Kalay) in the country's north-west advances the patchy knowledge base on climate-related risks in Myanmar. Our overarching objective is to understand how a few days of intense rainfall and wind that Komen brought on resulted in a disaster with lasting consequences for households' income and food security. We reason that the Komen case can serve to better understand communities' persistent vulnerability and exposure to climate-related hazards, including differences due to an altitudinal and agroecological gradient across our study site. Three research questions guided the inquiry: 
1. What were Komen's immediate impacts on farming systems and livelihoods in the study area, and how did this differ for up- and lowland households?

2. How did the disaster unfold, as Komen interacted with households' land-use practices, pre-existing vulnerabilities and farming challenges?

3. Which underlying drivers and livelihood outcomes of the disaster can be discerned, based on local peoples' knowledge about regional social-ecological system dynamics?

In contrast to most previous research on climate-related risks in Myanmar, we primarily address these questions through a local knowledge lens. Our analysis draws from participatory workshops facilitated with causal-diagramming techniques, complemented by data from in-depths interviews and household surveys. Most of our results therefore reflect our research participants' perceptions (as opposed to an 'objective' understanding) of the disaster, and how it was driven by local social-ecological system dynamics.

\section{Material and methods}

\section{Conceptual framework}

We adopt the United Nation's definition of disaster risk, as the 'potential loss of life, injury, or destroyed and damaged assets which could occur to a system, society or a community in a specific period of time' (United Nations Office for Disaster Risk Reduction 2020a, para. 1) and conceptualise climate-related disaster risk as a function of three parameters (Fig. 1):

- Climate-related hazards, i.e. climate-related processes or phenomena 'that may cause loss of life, injury or other health impacts, property damage, social and economic disruption or environmental degradation' (United Nations Office for Disaster Risk Reduction 2020c, para. 1).

- Exposure, i.e. 'situation of people, infrastructure, housing, production capacities and other tangible human assets located in hazard-prone areas' (United Nations Office for Disaster Risk Reduction 2020b, para. 1).
Fig. 1 Conceptual framework illustrating how the hazard (Cyclone Komen) interacts with exposed and vulnerable farming systems and livelihoods to produce a disaster. Also depicted are causal chains linking underlying disaster drivers to root-causes of households' exposure and vulnerability to climate-related hazards

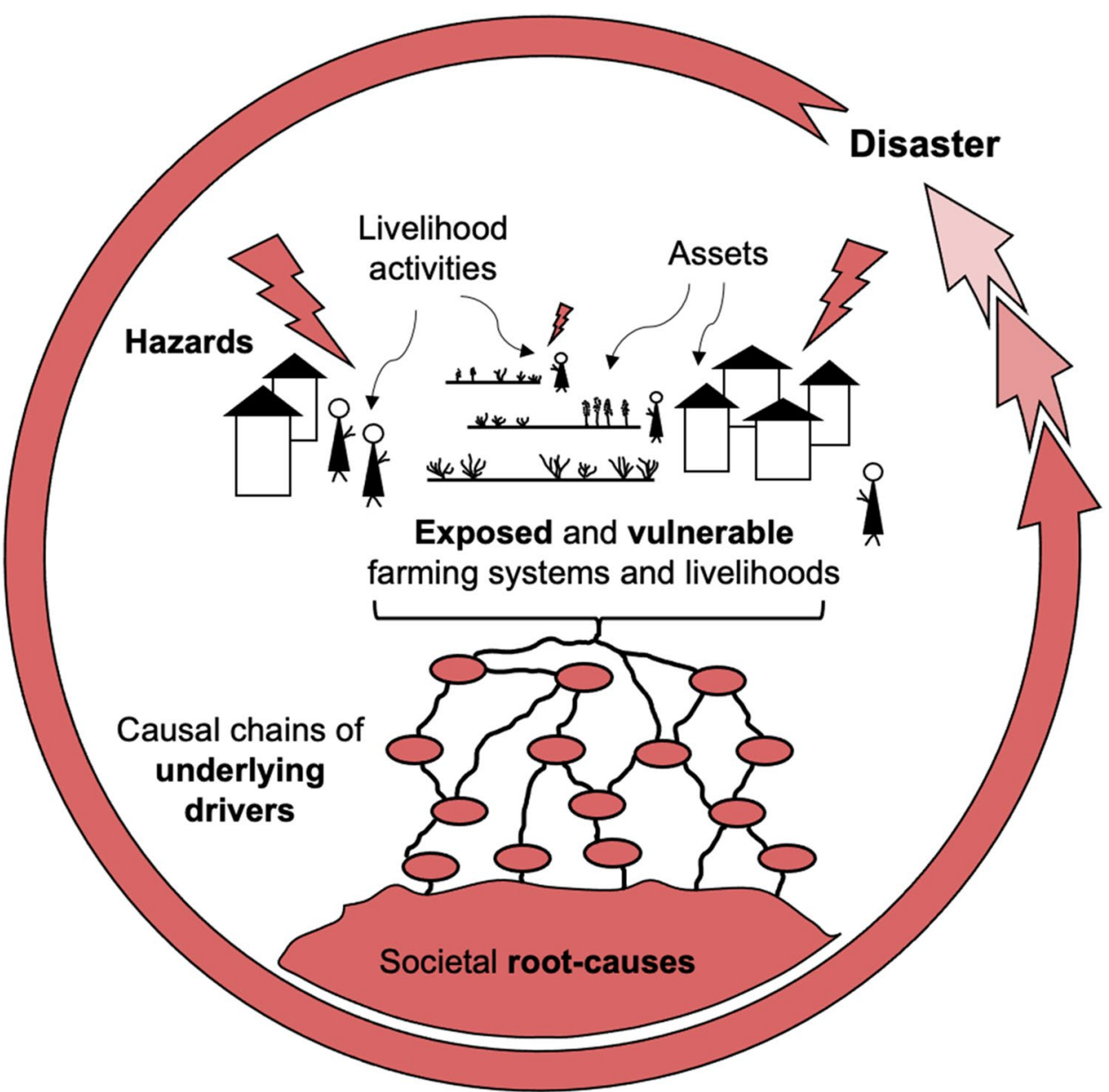


- Vulnerability, i.e. the 'opposite [of] security', which is households' 'defencelessness, meaning a lack of means to cope' with hazards, so that 'damaging loss' occurs (Chambers 1989, p. 1).

We describe Komen's impacts and underlying drivers of households' vulnerability, using key terms from the Sustainable Livelihoods Framework (Department for International Development 1999). This includes the notion of five assets (or capitals), on which households draw to support themselves and to cope in disaster situations: human capital-people's 'skills, knowledge, ability to labour and good health' (p. 19); social capital-people's 'social resources', grounded in trust relationships and network and group memberships (p. 21); natural capital-'the natural resource stocks from which resource flows and services [...] are derived' (p. 23); physical capital—'the basic infrastructure and producer goods needed to support livelihoods' (p. 25); and financial capital-people's 'financial resources' including both monetary inflows and savings (p. 27). Further, we refer to livelihood strategies - the activity portfolios that households engage in to meet their needs, and to livelihood outcomes - 'the achievements or outputs' from peoples' livelihood strategies (Department for International Development 1999, p. 37). We also explore how far our research participants could trace underlying drivers of the disaster, i.e. distant, societally grounded determining factors of hazards and households' exposure and vulnerability to them (Ribot 2013).

To discuss how Komen's impacts unfolded across time and various dimensions of households' farming systems and livelihoods, we refer to cascading disasters and escalation points. Cascades are disaster 'events that depend, to some extent, on their context and thus their diffusion is associated with enduring vulnerabilities. They are subject to a process of amplification of damage over time, and this can be distinguished by the presence of subsidiary disasters' (Pescaroli and Alexander 2015, p. 62). Escalation points are "critical juncture[s] in the chain of reactions to a disaster impact at which the interaction of vulnerabilities, and the concatenation of influences leads to a bigger impact than mere reaction to the primary disaster would suggest' (Alexander 2018, p. 181).

\section{Study area}

Our study area spanned three townships: Tonzang and Tedim in Chin State and Kalay in Sagaing Region. A national-level vulnerability assessment grouped these townships into a cluster with characteristically low levels of violent conflict, very low access to basic services and infrastructure and extreme sensitivity to irregular weather patterns and climate change (Humanitarian Assistance and Resilience Programme Facility and Myanmar Information Management Unit 2018). Topographically the study area features two distinct landscapes (Fig. 2): the first is characteristic of the entire Northern Chin Hills and spans an altitudinal gradient of more than $1500 \mathrm{~m}$. It features steeply sloped mountain ranges, marked by a patchwork of forests, fallows and swidden fields and narrow valleys with terraces, seasonally used for rice farming. The other comprises part of the Chin Hills' forested eastern foot slopes and an adjacent
Fig. 2 Map of Myanmar, with the study area's location indicated by the star symbol (a), and map of the study area (b). Shown in the latter are the upland (light yellow) and lowland (dark yellow) casestudy villages, major towns (reddish), Yazagyo Dam (light blue marker), the courses of the Manipur (light blue line), Nerinjara (medium blue line) and Myithar (dark blue line) rivers with selected tributaries, and part of the drainage divide separating the rivers' subwatersheds (white line). Images: Google Earth Pro, Landsat/ Copernicus: Data... (C) Images: Landsat/Copernicus; Data: SIO, NOAA, U.S. Navy, NGA, GEBCO, The World Bank
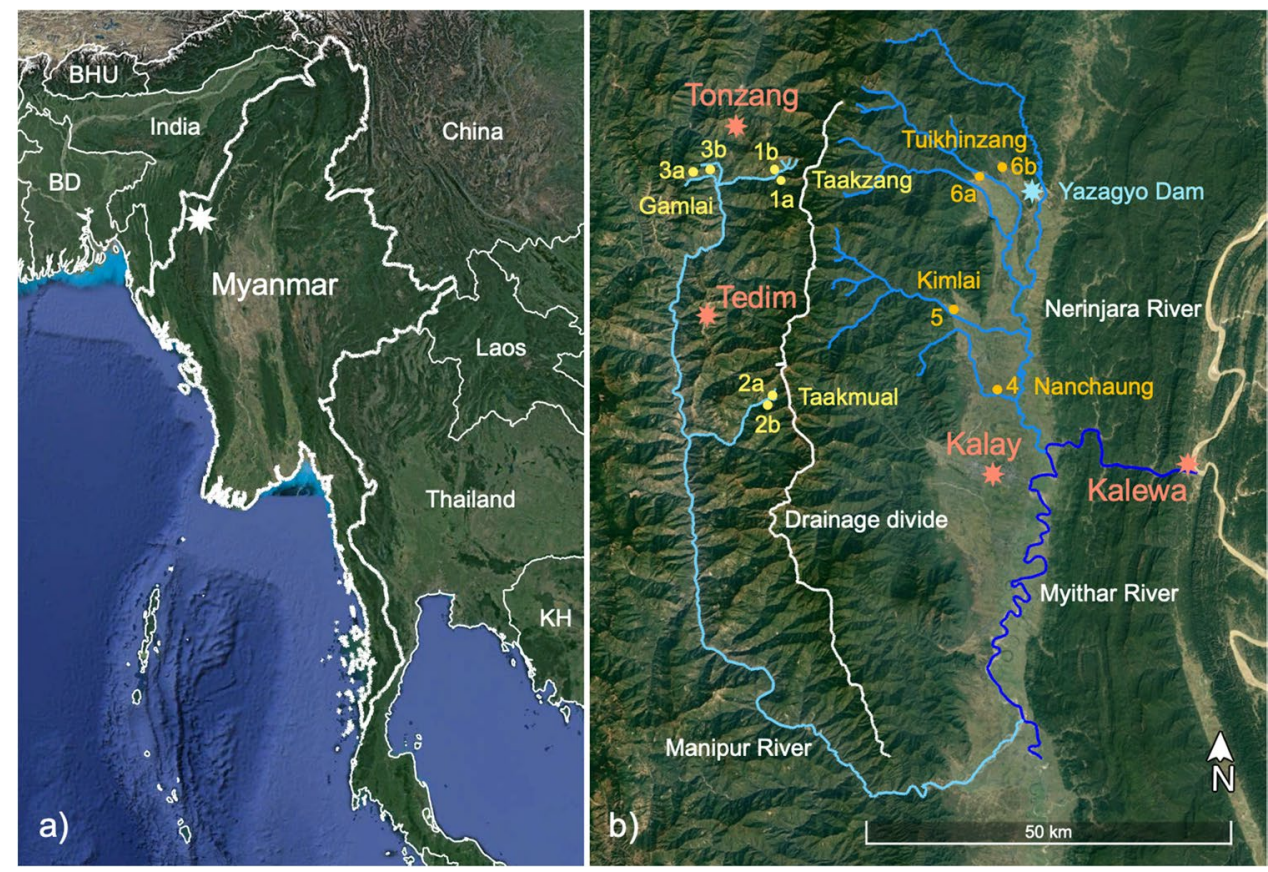
agriculturally dominated plain, typifying agroecological conditions in Kalay Valley. We treated households from these areas as distinct strata, referring to them as up- and lowland, respectively.

Different cropping systems and households' proximity to regional towns, markets and district-level agricultural authorities further set these strata apart. Upland households need to travel more than an hour on motorbikes to reach their townships centres Tonzang or Tedim, which lack major markets and host only township-level authorities. Lowland households have better road access to markets in the major regional city Kalay that also hosts township- and districtlevel agricultural authorities. Only one of the study villages belongs to Sagaing Region and is under these authorities' jurisdiction; however, all others belong to Chin State. Upland households mainly grow a variety of subsistence crops in homegardens and on swidden plots (Kmoch et al. 2021). Maize, groundnut, various beans and vegetables are typically sown in March and April, and winter crops such as mustards, cabbages, garlic, onion and tomatoes in September and October. Farm trees are common and access to paddy plots rare. Many lowland households grow monsoon paddy, and winter crops including groundnut, sunflower and various pulses for subsistence and surplus sales. Peas, green beans and cabbages are also commercially grown, and trees cultivated in homegardens. A substantial share of lowland households are landless and manage fields of Kalay city residents.

Up- and lowland households were exposed to dissimilar hazards as cyclone Komen passed. For upland households, the cyclone's passage was marked by strong winds and heavy precipitation, triggering landslides and severe surface runoff, with associated soil erosion on swidden fields and elevated water levels in rivers and streams. Lowland households were likewise exposed to torrential rainfall. Situated on the Nerinjara River floodplains, they experienced severe flash flooding, as the river and its tributaries normally feeding households' irrigation systems overflowed their banks. The catchments of the Nerinjara, Manipur and Myithar rivers normally drain into the Chindwin River, but rainfall brought on by the Cyclone added substantially to already elevated water levels in all four rivers. This resulted in water masses building up at the confluence of the Nerinjara and Myithar Rivers, which flooded Kalay city and villages and fields throughout the valley.

\section{Research approach and field campaign}

The research was conducted in partnership with the local NGO Ar Yone Oo Social Development Association (AYO) and designed in line with the United Nations Office for Disaster Risk Reduction's (UNDRR) premises that 'present and future approaches to managing risk require an understanding of the systemic nature of risk', and that through 'transdisciplinary, integrated, multisectoral research engaging non-traditional counterparts, risk assessment and decision-making efficiency can be improved' (United Nations Office for Disaster Risk Reduction 2019, p. ivf.). The field campaign ran from January to March 2018. At the time, AYO was implementing a multi-year relief, rehabilitation and development project (STRONG) to support the recovery and build resilience of cyclone-affected communities in the study area. The first author and two AYO employees, without prior engagement in AYO's STRONG project activities (to minimise bias), realised the field campaign.

Participatory causal-diagramming activities with farmers were our main means to gain insight into local peoples' disaster experiences, their knowledge about local social-ecological system dynamics and their vulnerability and adaptive capacity to cyclone hazards. This approach to engaging local knowledge holders is - inter alia — rooted in soft systems methodology and system dynamics traditions (Midgley 2015; Rodriguez-Ulloa and Paucar-Caceres 2005). Thinking in terms of 'explanatory or causal chains, in which sets of cause-consequence relationships are linked hierarchically or interact with one another' is also common in complex social-ecological systems research, however (Turner et al. 2020, p. 498). Hence, we found this approach well-suited to address our research questions, especially in combination with in-depths interviews and a structured household survey, in line with established local knowledge research techniques (Walker and Sinclair 1998).

The fieldwork commenced in four phases (Fig. 3): the scoping phase served to gain an initial understanding of Komen's impact, the subsequent disaster and AYO's STRONG project activities, through a literature review and in-depth interviews with AYO staff $(n=3)$ and Kalay agricultural authorities $(n=2)$. Six case-study villages were purposefully selected to include up- and lowland communities from all three townships and to capture a range of cyclone impacts (from comparatively minor to severe) (Online Resource (OR) 1). A mind-mapping workshop revealed STRONG project staff's interest to better understand Komen's impact on rural households, their experiences with climate change and extreme events, and general farming challenges affecting their livelihoods.

During the second phase, eleven gender-differentiated participatory causal diagramming sessions (with 5-10 participants, except in Kimlai where $30+$ people attended) captured respondents' cyclone and disaster experiences and local knowledge about social-ecological system dynamics that determine their extreme-event exposure and vulnerability. All workshops were facilitated in local languages by AYO staff and the first author. Participants first identified common farming challenges, which they faced due to climatic and other factors. Recorded on cards, these served as initial causal-diagram nodes. Causes and effects of these 


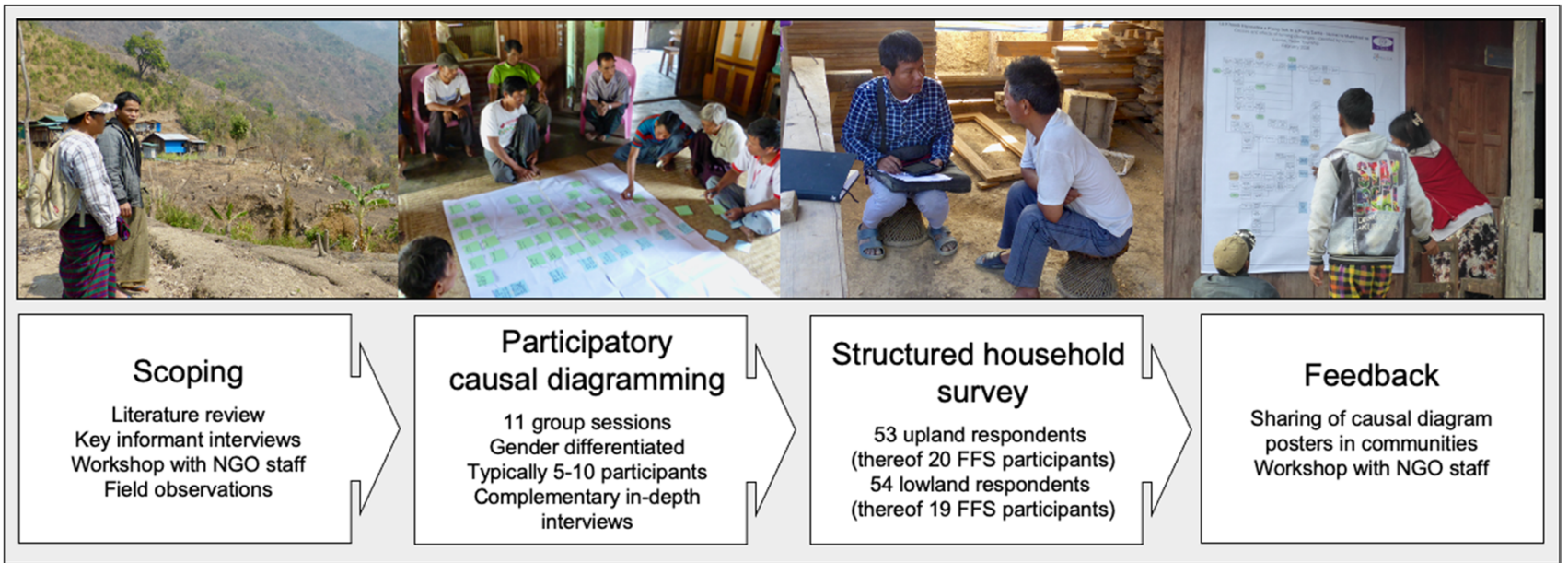

Fig. 3 Illustration of the 4-phase, mixed-methods research approach, i.e. the scoping, participatory causal diagramming, structured household survey and feedback phases of the field campaign

challenges were subsequently identified, and lines drawn to link all variables in causal loops and chains. Finally, participants identified own coping strategies and links to interventions that AYO realised in the cyclone's aftermath. Qualitative interviews with village residents and AYO staff served to deepen the inquiry.

A structured household survey was administered with hand-held tablets during the third phase, to a stratified random sample of 107 households from the case-study villages. The stratification was based on the landscape strata (up- and lowland) and respondents' membership (or not) in AYO farmer field school (FFS) groups. The final sample included 20 up- and 19 lowland FFS participants, and additionally 33 up- and 35 lowland non-FFS participants. We captured information about households' demographic composition, cropping systems, extreme-event experiences and farming challenges to statistically assess in how far preliminary findings from the first research phases reflected trends across the target population.

A feedback phase, to triangulate and share preliminary findings with AYO and research participants, concluded the field campaign. Reflections were recorded during a short workshop with STRONG project staff and when sharing posters with communities' causal diagrams in the study villages.

\section{Data analysis}

Paper-based diagrams resulting from the participatory causal-diagramming sessions were digitalised and analysed by iteratively comparing and synthesising the individual diagrams. Nodes and causal chains resonating with one another were grouped into themes, reflecting households farming system and livelihood vulnerabilities. Disaster-associated livelihood outcomes were found by identifying diagram nodes with many incoming but few outcoming causal links. Underlying disaster drivers were found by focusing on nodes with few incoming links. Nodes expressing the same meaning in different wording were consolidated, so that the emerging causal diagrams reflect an additional level of abstraction from the system dynamics that research participants' original diagrams captured. Summary statistics were computed using SPSS's Complex Samples to account for the overrepresentation of FFS participants among the survey respondents. In-depths interviews with rural households, AYO and agricultural authority staff were partially transcribed or recapped by listening to audio recordings using NVivo, to identify and synthesise statements relating to the research questions.

\section{Results}

\section{Komen strikes}

\section{Immediate impacts in upland communities}

Komen's immediate impact in upland communities was threefold. First, rainfall-triggered landslides destroyed residential dwellings and irrigation channels for paddy fields in narrow valley bottoms. Roads to villages, towns and fields were damaged or blocked with landslide debris. Swidden fields, fruit orchards and paddy terraces were broken apart by landslides. Soil-surface cracks formed in orchards, which exposed tree roots and led to the stands' decay. Landslides also rendered fields unsuitable, where fertile topsoil was lost, or debris accumulated. Second, heavy precipitation led to substantial surface run-off. Water masses, together with 
strong winds, toppled households' maize plants, coated them in mud and washed fertile topsoil off fields. Third, water accumulated in rivers and streams. This rendered already damaged and blocked-off roads impassable. Households were effectively trapped in their villages for several weeks, cut off from external help and unable to tend to their fields or send their children to school. Along streambeds and in narrow valley bottoms, water accumulated and washed away landslide-damaged paddy fields. The cyclone's impacts in Taakzang and Taakmual village were so severe that their residents eventually moved to new settlements on adjacent hillsides, which greatly increased the distance between their former fields and homes (OR 2).

\section{Immediate impacts in lowland communities}

Komen's impacts on lowland communities followed different paths. Paddy fields, homegardens and other cropland in all lowland villages were submerged, as floodwaters overflowed riverbanks and destroyed or inundated houses roof high. The flood destroyed households' monsoon crops, fruit trees and stored seeds, and left a thick layer of water-logged mud and tree $\log$ s behind, once it receded from farmers' fields.
Community infrastructure including roads, bridges, drinkingwater sources, open drains, latrines and irrigation channels were destroyed, households' farming activities disrupted, and their villages initially inaccessible by car. Nanchaung's residents had to temporarily leave their village, as the flood lasted for weeks. Tuikhinzang village was destroyed by masses of water and mud, which washed off the Chin Hills' eastern foot slopes through streams that were formerly used for irrigation, and its residents eventually relocated (OR 3 ).

\section{Disasters unfold}

\section{Interactions with households' land-use practices}

Following Komen's immediate impacts, disaster situations unfolded along several interlinked paths (Fig. 4; Fig. 5). Through damage to material assets, community infrastructure and fields, the cyclone first disrupted farmers' landuse practices, and through that many households' entire livelihoods.

Upland households particularly suffered from harvest shortfalls during the first post-cyclone months. Their crops

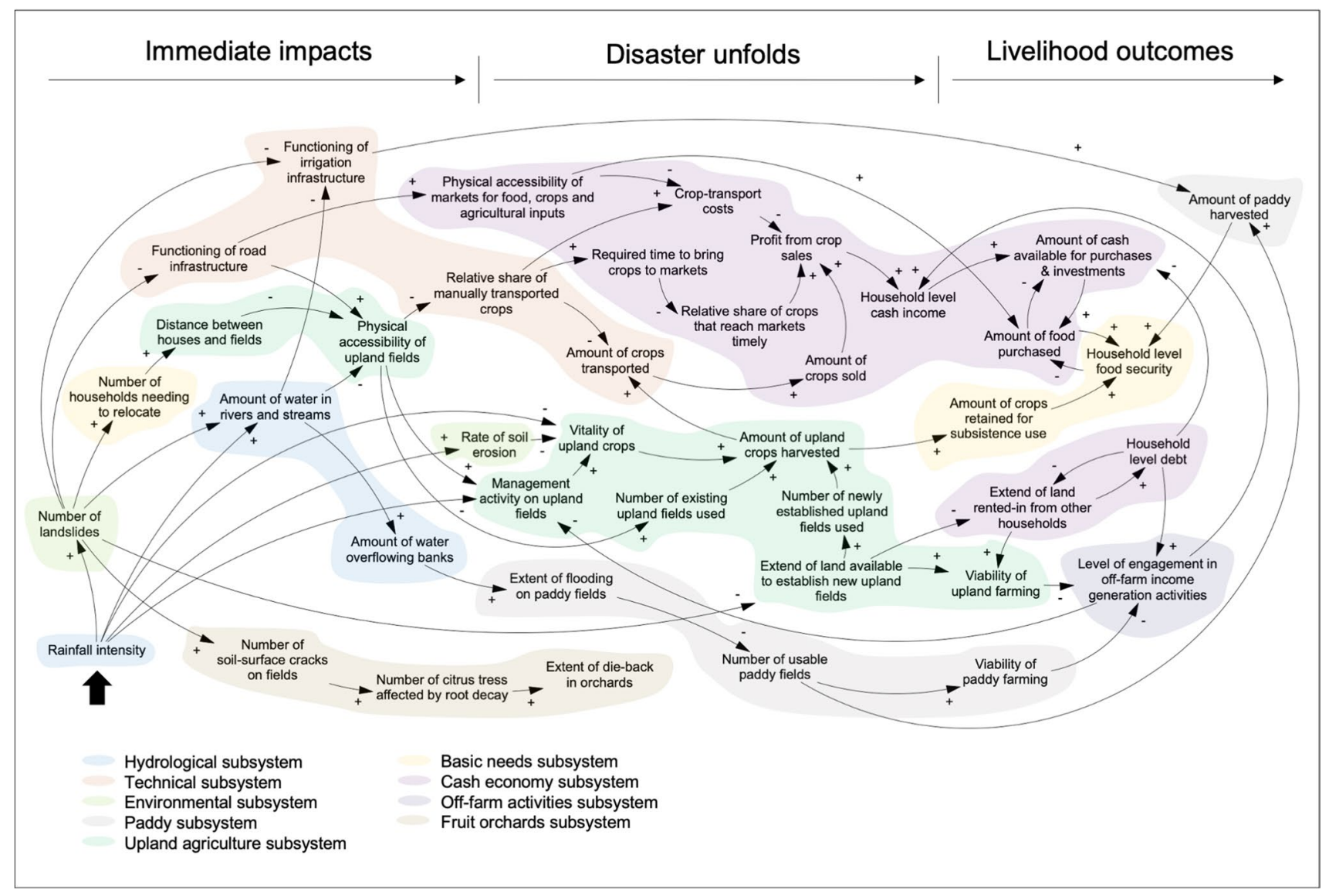

Fig. 4 Social-ecological system dynamics as the disaster cascaded across subsystems (coloured fields) as perceived by upland respondents 


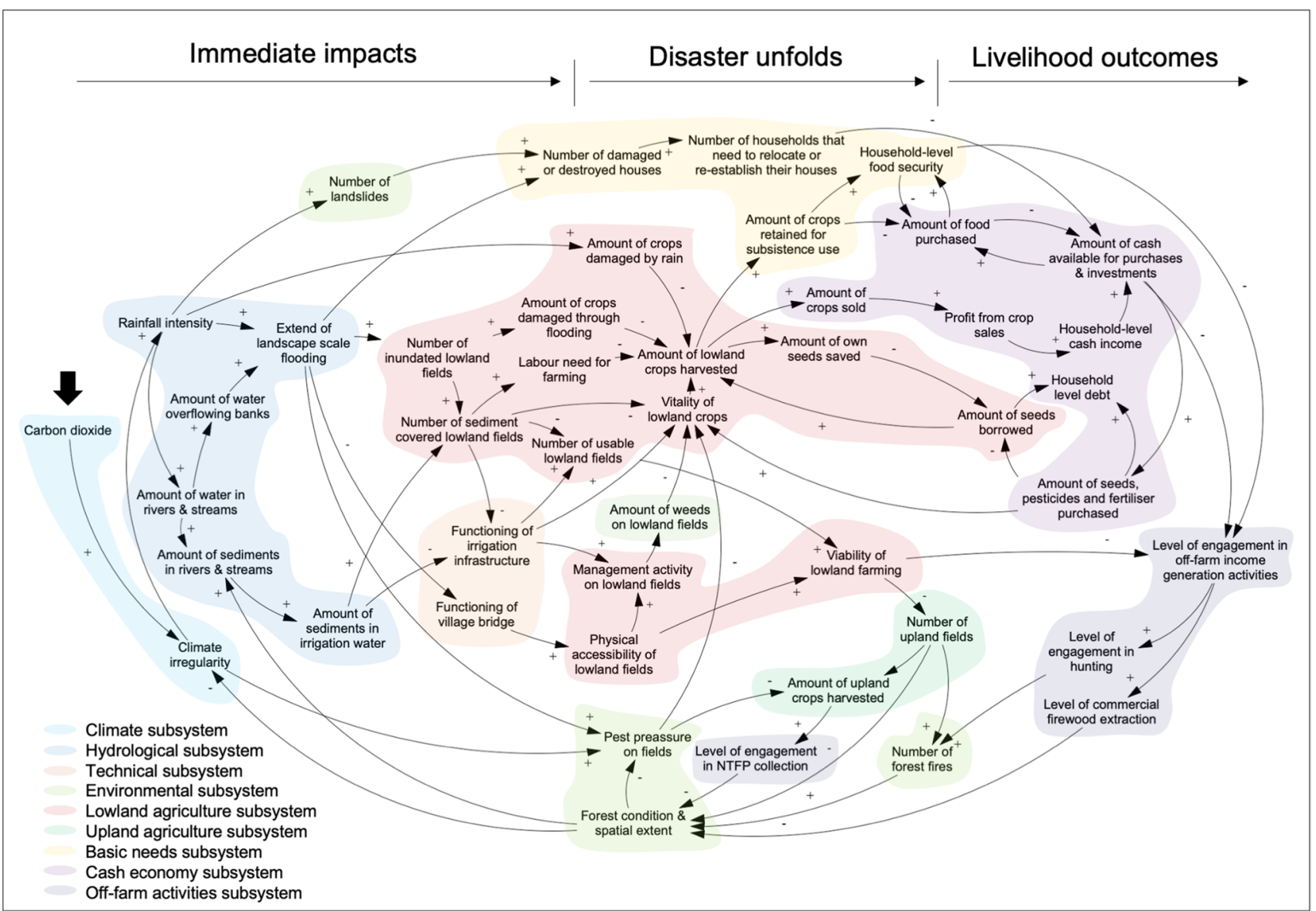

Fig. 5 Social-ecological system dynamics as the disaster cascaded across subsystems (coloured fields) as perceived by lowland respondents

had been damaged by Komen and were subsequently little managed, as it had become too difficult or time consuming for farmers to reach their fields. Most households could retain no or fewer subsistence crops than usual and therefore experienced food insecurity. A second food-insecurity pathway arose, as damaged roads led to greatly increased crop-transport costs and labour needs. Households thus made little profits from crop sales and lacked cash to buy food or invest for coming cropping seasons. Years after the cyclone, many respondents still suffered from food insecurity due to indebtedness resulting from households' inability to (re-)gain access to sufficient productive land and inputs to meet their food needs. Others had taken out loans to rent land, which they struggled to repay. Pushed into precarious off-farm income generation activities, by debt, cash shortages and food insecurity, many of these households now lacked time to manage their land.

Disaster-affected lowland households also struggled to resume their farming routines for years to come. Most tried to restore their houses and retrieved remaining physical possessions in the first post-cyclone months. Their monsoon crops had been destroyed by the flood, and seeds for the coming winter-cropping season lost. Even households who purchased or received seeds from relief actors were initially unable to re-sow, as community infrastructure to access and irrigate fields remained destroyed and farmers lacked machines to clear mud and log deposits off their land. District-level agricultural authorities helped to restore some fields near Kalay but stopped operating when fuel funds from Japan's International Cooperation Agency were used up. Communities further afar never received such assistance and were, at least in the first cyclone year, unable to drain and clear their water-logged fields by themselves. This was, as their irrigation channels remained filled with mud and indistinguishable from former fields and because the land was too unstable for ploughing with draught animals.

In subsequent years, once most fields had somewhat dried out, households' still endured cyclone-related production shortfalls. Some, because they could only broadcast seeds, as their land otherwise remained too wet to plant. Others, due to a flood-related rat plague, particularly in Nanchaung, where respondents also reported that their crops now often 
yellowed and decayed weeks after germinating, due to soil property shifts caused by the flood. Kimlai's residents struggled with sand from upstream sources, which irrigation water deposited on their fields since the extreme event. This caused crop losses, through increased labour needs and lowered crops vitality, making lowland farming unviable for affected households. Also, much land remained physically inaccessible or overgrown because respondents lacked motivation, time and physical capital to restore their obstructed fields. In Tuikhinzang, most farmers had permanently lost their paddy plots. Households with access to labour and draught animals therefore cleared new land near their resettled village. Others attempted to cope through swidden farming on nearby hillsides or engaged in off-farm work, if they lacked assets or land access to farm at all.

\section{Interactions with pre-existing vulnerabilities and farming challenges}

Komen's impacts may have pushed some households into food and cash insecurity, debt, and reliance on off-farm income generation activities for the first time. Many, however, already endured these circumstances before the cyclone struck. Key factors which drove their precarious livelihood circumstances included (i) limited land access, (ii) land degradation processes, (iii) climatic stressors, (iv) agricultural pests and diseases, and (v) households limited physical, social, human, and financial capital (OR 4). Komen exacerbated - but did not alone cause - these problems, which drove local farming challenges and households' vulnerability to the cyclone, as outlined below.

Limited land access was a farming barrier across the entire study area. Accessible swidden land in upland communities was already scarce before the disaster, due to population growths and some villages' small territories. Landless or land poor households, who sought to expand their cultivation area but could not gain access to land of their relatives, or with village head's approval, rented land at high costs. Others had to use own or rented swidden plots for more years than desirable, without fallowing. Yields on such land were low, due to declining soil fertility and increasing weed pressure. Purchasing paddy land or swidden plots near roads (rather than far from villages, on steep flanks) was too costly for most food and cash insecure households. Hence, they typically bore high costs for hired labour and equipment to transport their harvests and experienced profit shortfalls when their produce reached markets delayed. These pre-existing challenges made it all-the-more difficult for landslide-affected households to (re-)gain land access, after the cyclone had struck.

Lowland households' pre-disaster farmland access was restricted by government provisions against swidden farming on the Chin Hills' forested eastern flanks. Swidden farming was nonetheless a coping strategy of some landless lowland farmers, but not for widowed women with care duties, illness-affected households, or recent in-migrants, who lacked the required labour for swidden farming. Chronic lack of human capital in Komen's aftermath was also disadvantageous for poor households from Tuikhinzang. Short of labour and arriving late at their village's resettlement side, such households could not claim and clear new fields for themselves and therefor depended on land-rentals from earlier arrivers, if they farmed at all. Yet, even better-off households, who successfully claimed access to new land, faced impediments as the soil on their newly cleared fields was shallow, rocky and held little water. They also lacked draught animals to plough, as a disease had killed most of lowland households' livestock during a dry spell in 2014 or 2015, when streams had dried out and the animals lacked water to wash and cool off.

Land degradation processes likewise hampered up- and lowland households' farming success already prior to the disaster. Upland households attributed soil fertility losses and erosion processes to declining landscape-scale tree cover, forest fires, landslides and heavy rainfall events. Trees were cut to meet subsistence and commercial fuelwood and construction timber needs, and by poor households for harvesting valuable non-timber forest products (e.g. orchids). The establishment of ever new swidden fields, in response to soil fertility declines, increasing weed pressure and unintended forest fires (triggered when remnant vegetation and dormant seeds on fields were cleared to ease ploughing) was an additional driver. Landslides amplified land-productivity declines, through deposition of rocky debris. In Komen's aftermath, these processes made it hard for disaster-affected households to produce sufficient crops on their remaining fields and to find fertile fallows to be taken into production.

Agricultural soils in the lowland plain were already prior to Komen perceived as too 'sweet' or 'salty', which was attributed to continuous crop cultivation for the past 40-60 years. Respondents wished to amend their soils but lacked soil test equipment and knowledge to identify suitable products or calculate desirable input application rates. Households who used fertilisers often borrowed or purchased them against expected harvests and became indebted when yields remained below expectations. These barriers also stood in the way of lowland farmers' production success once the disaster occurred. Many could not afford inputs to amend the properties of their flood-altered soils and those who received fertilisers from relief programmes lacked knowledge to correctly apply them.

Climatic stressors hindering farmers' crop production included strong winds, heavy rainfall, and draught spells. Strong winds shook cash crops (various fruits) prematurely of trees. Rivers and streams often soared during the monsoon 
season and became impassable for upland farmers, trying to reach their fields. Maize plants grew unusually tall in sustained rainfall, which made them susceptible to toppling by wind, heavy rainfall, and eroding topsoil, which also coated toppled crops and small seedlings in mud. Unseasonal rainfall and drought spells caused harvest shortfalls, when seeds were too dry to germinate, or too moist and decayed. Affected farmers often lacked seeds to re-sow, incurred high costs and debt when travelling to towns to purchase seeds, or when borrowing planting material locally, at overly high interest rates. Late or replanted crops often matured untimely, which lead to profit losses. Immature crops were also frequently destroyed by dry spells.

Farmers' winter crop profits were low due to their produce's inferior quality. One reason for this was that crops were often damaged by unseasonal rainfall. Households who lacked draught animals were particularly affected by this, because they could not bring-in their wet harvest before it began to decay. Harvest losses in 1 year often perpetuated, when households lost too many crops to retain seeds for coming seasons. Upland households rarely grew dry-season vegetables, as they lacked affordable irrigation options and local streams dried up from rainfall shortages. Hotter dryseason days and erratic rainfall were also linked to increasing pest pressure and damage to already abiotically stressed plants. These chronic stressors hampered households' disaster recovery, as many worsened but none abated in the post-cyclone years.

Agricultural pests and diseases limiting households' predisaster farming success included seed-damaging pathogens, wild animals, free-ranging livestock, insects and diseases killing off community's draught-animal stock. Saved seeds were regularly lost, as households could not afford to treat them with pesticides for storage. Feeding wildlife caused crop failures and harvest losses, when farmers lacked labour to guard their fields. Pest problems were attributed to the local decline of forest habitat and wildlife food sources. Domestic livestock likewise frequently destroyed crops, as villages lacked common pastures. Metal fencing was too expensive to purchase, and wooden fences decayed too fast to maintain. Grasshopper and rat plagues regularly decimated lowland farmers' crops, not in all years, and plant pathogens often affected entire fields, once crops had first been damaged by wildlife.

Pest insects frequently damaged crops and caused harvest delays and seed shortages, when crops had to be re-sown or failed setting seeds. Farmers attributed such insect damage to a lack of knowledge about pesticides, missing financial capital and market access to purchase inputs, and government provisions against the use and sale of pesticides on lowland farms. Winter crop pest insect were further linked to a new weather pattern in the lowland, characterised by lack of rainfall, cloud cover and fewer misty mornings between September and May.
Some of these pest-related challenges were amplified by the flood, e.g. the rat plague that decimated lowland farmers' crops for years after the cyclone. Others, which were more chronic, nonetheless diminished households' disaster-recovery chances or coping success.

Limited physical, social, human and financial capital hampered households' farming success before and throughout the unfolding disaster. Upland respondents, already prior to Komen, lacked tools and funds to terrace cropland, establish irrigation systems, build durable fences or repair communal roads. They lacked cash and market access to purchase agro-industrial inputs (e.g. fertiliser, pesticides, hybrid seeds), land, draught animals, and hand and motorised tools to clear trees, plough and weed their fields. Lowland households likewise lacked funds for major farm investments but had better market access to purchase inputs.

Both strata faced farm-labour shortages due to household members' poor health, care duties, casual employment and seasonal or longer-term outmigration. Farm activities often fell behind schedule, as most farm work was labour intensive, manually conducted and disrupted when chronically indebted and food-insecure households had to seek employment to meet immediate needs, e.g. as farm labourers for inkind food payments. Already labour short households, such as women with small children dependent on their husbands' income, or widows dependent on community support, lacked time to acquire formal agricultural skills, even where trainings were locally offered. Others could not put their new skills into practice, for lack of tools or material inputs. Social conflicts impeded lowland farming success, e.g. when tensions arose about wet soil on paddy plots, which hampered crops' development on adjacent fields.

The cyclone amplified households' capital shortage, at a time when land, livestock, tools and agricultural inputs were most needed to restore fields and rebuilt farmers' livelihoods. Labour was in even shorter supply, as community members fell ill (e.g. from mosquito-borne diseases and low hygiene) and households balanced more laborious farm work, with recovery work and accident-prone coping strategies. Lacking social cooperation was felt, when households insufficiently cooperated to clear new land or tackle floodrelated pest outbreaks.

\section{Causal roots and branches}

\section{Underlying drivers}

In addition to pre-existing vulnerabilities, our respondents also identified several underlying hazard drivers, which fuelled the disaster. In upland communities, the disaster was triggered by intense rainfall that caused landslides and valley flooding. Respondents attributed these variables to climate irregularities and a loss of landscape-scale tree cover 
(Fig. 6). These underlying hazard drivers were rooted in accelerating erosion rates, households' need to clear swidden land and their forest dependance to meet basic livelihood needs, in absence of alternative cash-income sources. Lowland households likewise cut trees to earn cash and meet own needs, while outsiders' forest use drove deforestation in both strata. Residents of Tedim used village forests to source commercial forest goods, while logging elephants damaged crops in the lowland, where respondents also perceived timber smugglers and outsiders harvesting fuelwood (for lack of electricity and to supply a nearby brick factory), as a threat. Only one respondent group linked climate irregularities to high levels of atmospheric $\mathrm{CO}_{2}$.

\section{Livelihood outcomes}

Key variables in all causal diagrams pertained to persistent crop failures and low yields, food insecurity and respondents' chronic shortage of cash for farm investments and basic needs (Fig. 7; OR 5). These variables were both underlying drivers of cyclone vulnerability and other adverse livelihood outcomes in the study area. Disaster-affected, indebted and food insecure households experienced physical and mental illness, violence, fear and concern about their low social standing. Those who lacked cash often ended their children's education, sold productive assets, were pushed into precarious wage labour, engaged in physically dangerous and illegal forest-reliant coping strategies (hunting, harvesting orchids, commercial timber and fuelwood extraction) or migrated abroad, with potentially devastating social repercussions. Many were trapped in reinforcing negative dynamics: loan obligations could only be met through further loans; asset poverty and little time to farm led ever deeper into wage dependencies; children's job prospects diminished, as they left school and engaged in casual labour; and peoples' health and labour ability deteriorated, for lack of nutritious food and medical care.

\section{Discussion}

\section{Two disasters unfolded in Komen's wake}

Our analysis of Komen's immediate impacts shows that both strata experienced severe adversities in the cyclone's aftermath. Many households lost their material assets, land-use activities were disrupted, and villages had to relocate. Yet, Komen triggered different secondary hazards and interacted

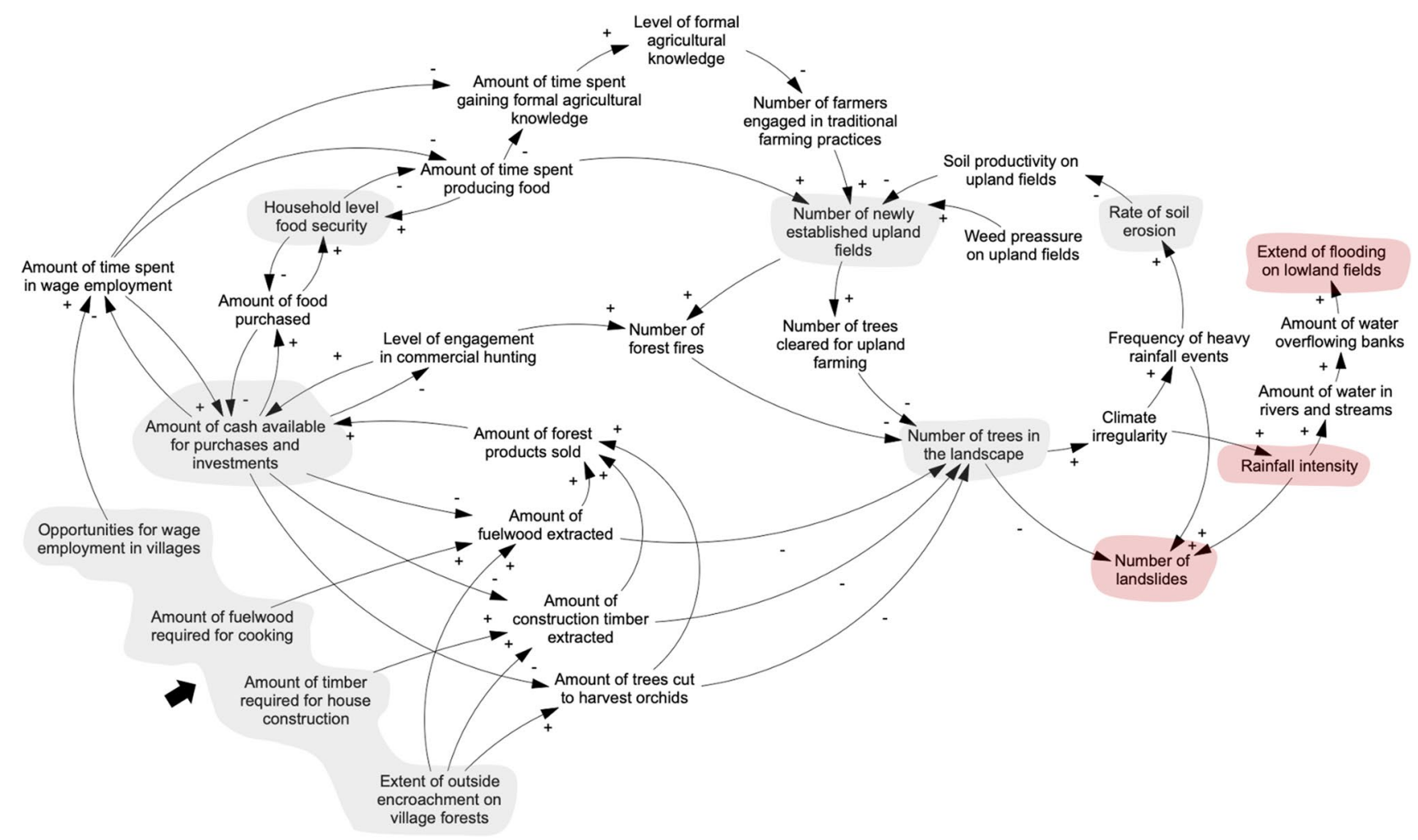

Fig. 6 Causal diagram of underlying hazard drivers that upland respondents perceived. The figure illustrates perceived underlying disaster drivers (grey) and their links to hazards (red) that affected upland households during the cyclone's traverse. Plus signs (+) on arrows linking variables indicate change in the same direction, minus signs ( - ) change in the opposite direction 


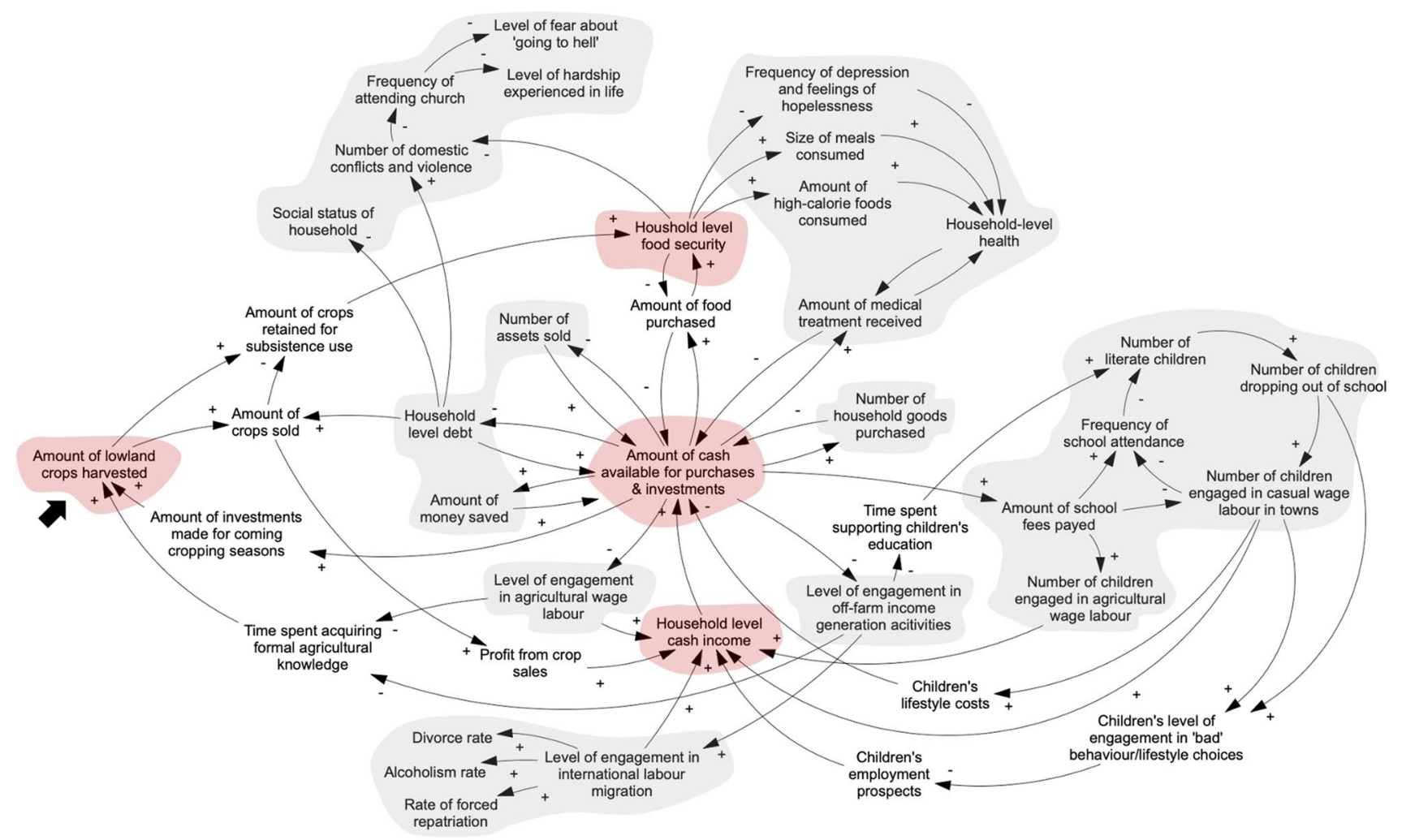

Fig. 7 Causal diagram of livelihood outcomes that lowland respondents perceived. The figure illustrates perceived livelihood outcomes (grey) and critical drivers of livelihood (in-)security (red) that low-

with disparate landscape features and land-use practices in up- and lowland communities, causing the unfolding disaster dynamics to take disparate paths. Komen, and the system dynamics unfolding in its wake, are therefore best understood as a single initial hazard, which triggered distinct disaster situations in the two strata.

Two emerging abstractions of disasters in the literature help explain how these disasters unfolded: the notion of cascading disasters and escalation points, and the concept of extensive disasters, i.e. 'recurrent, small-scale, low-severity disasters', which are primarily rooted in poverty and social inequalities, rather than rare, system-external hazards (United Nations Office for Disaster Risk Reduction 2015, p. 90). Seen through the cascade lens, the post-Komen disaster dynamics appear as follows: the flash flood in the lowland, which inundated fields and destroyed houses, seeds and critical transport and irrigation infrastructure, was a secondary hazard. Although devastating, this was not the culmination, but rather an escalation point of the unfolding dynamics, as the flood itself was not the greatest post-cyclone challenge for most households. Their real predicament arose from the thick layer of water-logged mud that remained on farmers' plots, and the continued deposition of sediments on farmland, in subsequent years. Households likely could have land households associated with the disaster. Plus signs (+) on arrows linking variables indicate change in the same direction, minus signs (-) change in the opposite direction

resumed their agricultural activities with limited external support, if they had only lost the current seasons' crops and seeds. Their livelihoods were severely disrupted, however, as their income and food security were functionally dependant on the fields that had been destroyed or become unusable for several cropping seasons.

The failure of communities' irrigation and transport infrastructure amplified the crisis, as both were critical 'to the maintenance or restoration of [households'] normal activities' (Pescaroli and Alexander 2015, p. 61). Without irrigation water and physical access to fields, lowland farming became unviable, even for farmers whose fields remained undamaged by the flood. Yet, even here, the disaster did not end. Lowland households, who eventually ran out of food, cash or credit, experienced another escalation point. Threatened by imminent crisis, they were pushed into casual farm labour, off-farm work or distress migration and had to take their children out of school. Typical reasons for such crisis situation were that households could not amend their flooddamaged farm soil, lacked access to new, more fertile land, or lost their crops to pests, diseases and climatic stressors, if they tried to cope through swidden farming.

In the uplands, the cyclone also triggered several secondary hazards: flooding in valleys and numerous landslides. 
Yet again, the situation did not escalate due to immediate damage from these landslides. An escalation point was rather reached once households lost physical access to their remaining fields and could not resume their farming activities elsewhere, for lack of use rights for alternative swidden plots. Just as in the lowland, households' predicament escalated further, where debt or food insecurity pushed them into forest-reliant coping activities, distress migration and other off-farm work.

In short, the cascade lens reveals that the post-Komen social-ecological system dynamics were characterised by cascades and escalation points that 'substantially prolonged the emergency and [led] to effects that [...] overshadow[ed] the initial trigger event' (Alexander 2018). The unfolding disaster situations severely disrupted multiple domains of households' everyday life and land-use systems and affected communities for several years. Both disasters situations can therefore be classified as 'level 4' disasters 'with substantially complex consequences' (Alexander 2018).

What the cascade lens does not reveal, is how the disaster was amplified at critical escalation points along the cascade chains. This is where the concepts of extensive disasters aid understanding of the disasters' unfolding. Cascades' propagation 'is fundamentally related to vulnerability' (Pescaroli and Alexander 2015, p. 60) and our analysis shows that not just escalation points, but also pre-existing farming challenges substantially hampered households' farming success. This highlights chronic stressors and extensive disasters as key drivers of households' vulnerability to Komen and similar events. Households certainly would have had more resources to cope with the cyclone's impacts, were it not for small-scale disasters that steadily eroded their food security, asset and cash-income base. A strength of our local-knowledge approach is that it revealed these extensive disasters, which usually 'remain largely unobserved and under-studied beyond the community affected by them' (Zaidi 2018, p. 308). These everyday events interacted with cyclone-triggered events in both strata, and thereby drove the escalation of local system dynamics into disaster.

The specificities of the post-disaster cascades, and differences in how they played out for up- and lowland communities, highlights the limits to national-level vulnerability assessments, which statistically attribute households' vulnerability to a few generic variables, based on readily accessible census and township-level administrative data (Humanitarian Assistance and Resilience Programme Facility and Myanmar Information Management Unit 2018). While useful for identifying data gaps in existing understanding, such state- and regional-level vulnerability assessments may also 'mask[...] differences within and between townships, village tracts and population groups' (Humanitarian Assistance and Resilience Programme Facility and Myanmar Information Management Unit 2018, p. 1). State-led and donor-funded adaptation schemes in Myanmar should therefore prioritise contextually grounded vulnerability assessments, which appraise location-specific landscape characteristics, land-use practices and livelihood dynamics that shape households' exposure and vulnerability to climate hazards. In addition to the present study, this is also exemplified by a recent township-level climate vulnerability assessment for Hakha (Chitale et al. 2019).

\section{Addressing climate-related livelihood risks}

With climate change projections indicating that Chin households will have to brace themselves for 'increased flash floods and landslides, strong winds, increased temperature, and erratic rainfall with greater amounts of rain within a shorter monsoon season' (Chitale et al. 2019, p. vi), action to address associated livelihood risks is urgently required. The distinction of cascading and extensive disasters highlights two key strategies for such action. First, functional dependencies in the affected social-ecological systems can be reduced, by diversifying households' livelihoods and land-use practices (Hallegatte et al. 2020) and increasing redundancy (of critical infrastructure, accessible land and physical capital, e.g. draught animals) to mitigate the risks of future disaster cascades (Alexander 2018). Achieving this requires a long-haul development effort, including persistent investments in local social, physical and natural capital.

Second, future escalations through the disruption of households' farm activities and means to gain access to food and cash can be avoided, if state authorities provide poor households with more comprehensive and timely support. This entails short-term disaster relief: early technical and material assistance to restore critical infrastructure, clearing fields from sediments or securing access to suitable farmland, to enable households to swiftly (re-)gain food security. Targeted aid for those facing imminent food or debt crisis could obviate households' need to sell productive assets, engage in precarious wage labour or take children out of school - a hard-to-reverse disaster outcome that prevails throughout the world (Hallegatte et al. 2020). We found that most households had to rely on their own agency, assets and aid from non-governmental organisations, rather than state-authorities' support, to cope with Komen's impacts. This fits with perceptions of a 'marginalising government response' and '[u]nion government [...] neglect' towards the disaster-affected Chin population in Komen's aftermath (Desportes 2019).

Yet, the households' vulnerability to the cyclone was also driven by factors beyond limited diversification, lack of redundancy and singular instances of neglect. Respondents' accounts of persistent stressors and extensive disasters that erode farmers' capital base and result in frequent crop failures, highlight poverty trap dynamics, which are both 
cause and outcome of households' vulnerability to extreme events. Local hazard drivers and households' exposure and vulnerability could be reduced, if long-neglected development needs in the study area, such as rural electrification, local income earning opportunities, legal and equitable land access, targeted extension services, access to agricultural inputs and markets were finally prioritised. This suggest that the argument of 'poverty reduction [... being] disaster risk management, and disaster risk management [... being] poverty reduction', also holds in western Myanmar (Hallegatte et al. 2020, p. 223).

\section{Conclusion}

As extreme events, including cyclones, gain intensity, it becomes ever more important to understand how disasters evolve through interactions of climatic hazards with exposed and vulnerable farming communities. This holds especially in Myanmar, where costs from disaster-related damages already amount to billions of dollars each year, and rural communities proximately depend on agroecosystems services to meet their basic needs. We set out to address this challenge by advancing existing knowledge about climate-risk drivers in western Myanmar, asking how cyclone Komen could trigger a disaster with long-term adverse impacts on rural livelihoods in our study area.

The key argument, advanced through our analysis, is that rural peoples' local knowledge and disaster experiences add crucial perspectives in efforts to disentangle social-ecological system dynamics that are at play, when climate-related disasters emerge. If these perspectives are ignored, we may fail to understand local response strategies to disasters, and efforts to decrease local vulnerability may be well-intentioned but unsuited to local conditions and needs. Our research participants had unique insight into the disaster dynamics that unfolded in cyclone Komen's wake. They lived through this process after all, about which data was otherwise scarce. It is their knowledge, upon which we identified options to reduce climate risk in the study area and established that it was the conjunction of disaster cascades, with extensive disasters and households' disparate vulnerabilities, which caused the escalation of Komen's 2015 impacts into long-lasting disasters.

There are three main takeaways from our study, for policy makers, practitioners and researchers alike. First, households' hazard exposure and vulnerabilities differed markedly within and across two geographically proximate, yet disparate strata. Based on this finding, we call for more contextually grounded vulnerability assessments, as a basis for locally applicable climate-risk reduction interventions in Myanmar. Second, there is merit in analytically distinguishing the role of extensive disasters and cascades in disaster dynamics, as both highlight different entry points for prevention, relief and recovery efforts. Finally, both local and international actors bear partial responsibility for the hardship that households experienced in Komen's aftermath. Hence, we urge to step-up efforts that address underlying climaterisk drivers, and address rural communities' development priorities, in western Myanmar.

Supplementary Information The online version contains supplementary material available at https://doi.org/10.1007/s10113-021-01847-2 .

Acknowledgements We thank all research participants from the case study villages and the entire Ar Yone Oo team in Kalay for sharing their knowledge and participating in this study. Special thanks go to Sian Khat Mung and the late Myo Myint Win, for their substantial contribution to the study's field campaign, which was partially funded by a small grant from the Agroecology Learning Alliance in South-East Asia.

Funding Open access funding provided by Chalmers University of Technology.

\section{Declarations}

Conflict of interest The authors declare no competing interests.

Open Access This article is licensed under a Creative Commons Attribution 4.0 International License, which permits use, sharing, adaptation, distribution and reproduction in any medium or format, as long as you give appropriate credit to the original author(s) and the source, provide a link to the Creative Commons licence, and indicate if changes were made. The images or other third party material in this article are included in the article's Creative Commons licence, unless indicated otherwise in a credit line to the material. If material is not included in the article's Creative Commons licence and your intended use is not permitted by statutory regulation or exceeds the permitted use, you will need to obtain permission directly from the copyright holder. To view a copy of this licence, visit http://creativecommons.org/licenses/by/4.0/.

\section{References}

Alexander D (2018) A magnitude scale for cascading disasters. Int J Dis Risk Reduct 30:180-185. https://doi.org/10.1016/j.ijdrr.2018. 03.006

Chambers R (1989) Editorial introduction: vulnerability, coping and policy. IDS Bull 20:1-7

Chen A (2020) Tropical cyclone induced extreme wind, rainfall, and floods in the Mekong River Basin. Doctoral Thesis, University of Gothenburg

Chitale VS, Gibert M, Bhuchar S, Capizzi P, Ling H (2019) Assessment of climate change vulnerability of Hakha Township, Chin State, Myanmar 2017-2050: scenarios for resilience building. ICIMOD and UN-Habitat/UN Environment, Kathmandu

Department for International Development (1999) Sustainable livelihoods guidance sheets. http://www.livelihoodscentre.org/docum ents/20720/100145/Sustainable+livelihoods+guidance+sheets/ 8f35b59f-8207-43fc-8b99-df75d3000e86. Accessed 15 Oct 2021

Desportes I (2019) Getting relief to marginalised minorities: the response to cyclone Komen in 2015 in Myanmar. Journal of International Humanitarian Action 4:7. https://doi.org/10.1186/ s41018-019-0053-Z 
FloodList (2020) Myanmar. http://floodlist.com/tag/myanmar. Accessed 15 Oct 2021

Gualdi S, Scoccimarro E, Navarra A (2008) Changes in tropical cyclone activity due to global warming: results from a high-resolution coupled general circulation model. J Clim 21:5204-5228. https://doi.org/10.1175/2008jcli1921.1

Hallegatte S, Vogt-Schilb A, Rozenberg J, Bangalore M, Beaudet C (2020) From poverty to disaster and back: a review of the literature. Econ Dis Clim Chang 4:223-247. https://doi.org/10.1007/ s41885-020-00060-5

Herridge DF, Win MM, Nwe KMM, Kyu KL, Win SS et al (2019) The cropping systems of the central dry zone of Myanmar: productivity constraints and possible solutions. Agric Syst 169:31-40. https://doi.org/10.1016/j.agsy.2018.12.001

Humanitarian Assistance and Resilience Programme Facility, Myanmar Information Management Unit (2018) Vulnerability in Myanmar. A secondary data review of needs, coverage and gaps. Yangon, Myanmar

International Federation of Red Cross and Red Crescent Societies (2017) Final report Myanmar: floods. https://reliefweb.int/sites/ reliefweb.int/files/resources/MDRMM006FR.pdf

Kmoch L, Palm M, Persson UM, Jepsen MR (2021) Access mapping highlights risks from land reform in upland Myanmar. J Land Use Sci 16:34-54. https://doi.org/10.1080/1747423x.2020.1836053

Knutson TR, McBride JL, Chan J, Emanuel K, Holland G et al (2010) Tropical cyclones and climate change. Nat Geosci 3:157-163. https://doi.org/10.1038/ngeo779

Midgley G (2015) Systemic Intervention. In: Bradbury H (ed) The Sage handbook of action research. Third Edition edn. Sage, London, pp 157-165

Pescaroli G, Alexander DW (2015) A definition of cascading disasters and cascading effects: going beyond the "toppling dominos" metaphor. GRF Davos Planet@Risk 3:58-67. Davos: Global Risk Forum GRF Davos.

Ribot J (2013) Vulnerability does not just fall from the sky: towards multi-scale pro-poor climate policy. In: Redclift MR, Grasso M (eds) Handbook on climate change and human security. Edward Elgar Publishing Limited, Cheltenham, UK, pp 164-199

Rodriguez-Ulloa R, Paucar-Caceres A (2005) Soft system dynamics methodology (SSDM): combining soft systems methodology (SSM) and system dynamics (SD). Systemic Practice and Action Research 18:303-334. https://doi.org/10.1007/s11213-005-4816-7

Schneider P, Asch F (2020) Rice production and food security in Asian mega deltas - a review on characteristics, vulnerabilities and agricultural adaptation options to cope with climate change. J Agron Crop Sci 206:491-503. https://doi.org/10.1111/jac.12415
The Republic of the Union of Myanmar (2019) Myanmar climate change strategy (2018-2030). https://myanmar.un.org/en/downl oad/5102/26016. Accessed 15 Oct 2021

Tun Oo A, Van Huylenbroeck G, Speelman S (2018) Assessment of climate change vulnerability of farm households in Pyapon District, a delta region in Myanmar. International Journal of Disaster Risk Reduction 28:10-21. https://doi.org/10.1016/j.ijdrr.2018.02.012

Tun Oo A, Van Huylenbroeck G, Speelman S (2017) Determining factors for the application of climate change adaptation strategies among farmers in Magwe District, dry zone region of Myanmar. International Journal of Climate Change Strategies and Management 9:36-55. https://doi.org/10.1108/ijccsm-09-2015-0134

Turner BL, Meyfroidt P, Kuemmerle T, Müller D, Roy Chowdhury R (2020) Framing the search for a theory of land use. J Land Use Sci 15:489-508. https://doi.org/10.1080/1747423x.2020.1811792

United Nations Office for Disaster Risk Reduction (2015) Global assessment report on disaster risk reduction. https://www.preve ntionweb.net/english/hyogo/gar/2015/en/gar-pdf/GAR2015_EN. pdf. Accessed 15 Oct 2021

United Nations Office for Disaster Risk Reduction (2019) Global assessment report on disaster risk reduction. United Nations Office for Disaster Risk Reduction (UNDRR), Geneva, Switzerland

United Nations Office for Disaster Risk Reduction (2020a) Disaster risk. Terminology. https://www.undrr.org/terminology/disasterrisk. Accessed 15 Oct 2021

United Nations Office for Disaster Risk Reduction (2020b) Exposure. Terminology. https://www.undrr.org/terminology/exposure. Accessed 15 Oct 2021

United Nations Office for Disaster Risk Reduction (2020c) Hazards. Terminology. https://www.undrr.org/terminology/hazard. Accessed 15 Oct 2021

United Nations Office for the Coordination of Humanitarian Affairs (2015) OCHA flash update no 1: Myanmar floods emergency. https:// reliefweb.int/report/myanmar/ocha-flash-update-no-1-myanmarfloods-emergency-01-august-2015. Accessed 15 Oct 2021

Walker DH, Sinclair FL (1998) Acquiring qualitative knowledge about complex agroecosystems 2. Formal Representation Agricultural Systems 56:365-386. https://doi.org/10.1016/s0308$521 x(97) 00049-8$

Zaidi RZ (2018) Beyond the Sendai indicators: application of a cascading risk lens for the improvement of loss data indicators for slowonset hazards and small-scale disasters. Int J Dis Risk Reduct 30:306-314. https://doi.org/10.1016/j.ijdrr.2018.03.022

Publisher's note Springer Nature remains neutral with regard to jurisdictional claims in published maps and institutional affiliations. 